\title{
REGIONAL RELATIONSHIPS OF MAXIMUM OUTFLOW IN THE UPPER BÓBR RIVER BASIN
}

\author{
Dorota Olearczyk ${ }^{1}$, Radosław Stodolak $^{1}$ \\ 1 Institute of Environmental Engineering, Wrocław University of Environmental and Life Sciences, pl. Grun- \\ waldzki 24, 50-363 Wrocław, Poland, e-mail: dorota.olearczyk@up.wroc.pl; radoslaw.stodolak@up.wroc.pl
}

Received: 2015.09.16

Accepted: 2015.10.06

Published: 2015.11.10

\begin{abstract}
The paper presents the results of the estimation of the runoff formation during floods events in the upper Bóbr River basin, including its left-sided tributary the Kwisa River. The analysis was carried out on the basis of historical maximum freshets recorded at 15 gauging stations located on the streams and rivers in the investigated area in multiyear 1970-2004. For all standardized freshets the basic parameters were determined: reduced maximum discharge, duration times and volumes for wave phases, rising and falling and for total wave. On the basis of these parameters the regional relationships of maximum outflow were determined for the Bóbr River basin. The obtained results are satisfactory, most of the relationships proved strong correlations, confirmed by high values of determination coefficients. Determined regional relations between the waves' parameters give a view on the course of flood events and the maximum outflow formation in the basin and can be useful in engineering issues in the studied region.
\end{abstract}

Keywords: flood wave parameters, regional relationships of maximum outflow.

\section{INTRODUCTION}

The Sudeten Mountains is the region which is not very well recognized in terms of runoff formation, particularly during floods occurrence. Lack of elaborations causes that it is impossible to estimate the maximum outflow from rivers and streams that flow from mountains. This issue is very important because some of the rivers which have their sources in mountains supply in waters the upper and middle Odra River, sometimes causing the superposition of flood waves of tributary and recipient during flood events. This phenomenon creates an additional threat in the Odra River valley. The Sudeten Mountains themselves are vulnerable to flooding. Floods occur frequently and the flood risk is high, especially in mountain valleys and for towns and villages located along the rivers and streams. Therefore, it is worth to know the quantity of water that is drained by mountainous watercourses during floods. Such information will be useful for engineering issues related not only to flood protection but also to water retention (what volume of water can be stored in reservoirs not to lose it irrevocably) and to operating the devices of hydrotechnical structures during flood passage.

The authors studied some of the Sudeten tributaries of the Odra River and in this paper the results of estimating a maximum outflow from the Bóbr River with its tributary, the Kwisa River are presented. There is a need to recognize well the conditions of runoff formation in the upper basins of these rivers during flood occurrence. Some attempts to determine regional relationships of maximum discharges in the investigated region have been done by Olearczyk [2001], but they are related only to one parameter of flood wave, i.e. maximum flow, others like duration and volume of wave have not been considered. That is why the authors included all the wave parameters in analysis.

The fact that the Bóbr River has a significant impact on flows of the Odra River is supported by the investigations of the Institute of Meteorology and Water Management [Dubicki et al. 2013]. The results indicate that the Bóbr River comes second, after the Nysa Kłodzka River, with the 
highest share in the mean runoff formation of the Odra River, which is $15 \%$.

The Bóbr River is the one of the biggest leftside tributary of the Odra River. The total catchment area is $5874.45 \mathrm{~km}^{2}$ and length $278.76 \mathrm{~km}$. Together with its left-side tributary - the Kwisa River, it drains the slopes of the Sudeten Mountains in their upper watercourses. Climatic conditions together with the topography of the catchment area favour the maximum freshets and flood occurrence. Numerous rivers, streams and watercourses in the upper Bóbr River and the upper Kwisa River catchments are supplied in waters mainly from rain in summer season and from snow in winter season what causes two maximum discharges within a hydrological year, summer (mainly July-September) and at the turn of winter and spring (February-April). The biggest in size and magnitude are summer freshets, while winter-spring freshets are suitably lower. The catchments average slopes in the investigated region vary from $3.5 \%$ to $19 \%$. A hydrographical network of the upper basins of two main rivers in the region, the Bóbr River and the Kwisa River is well developed and the drainage density is about $0.8 \mathrm{~km} \times \mathrm{km}^{-2}$. The mountainous nature of watercourses of the tributaries of the Bóbr River and the Kwisa River significantly influence the velocity of water mass motion and concentration time of freshet wave, causing thereby a rapid rise of water in streams and rivers. Floods events occur in this region very frequently. The biggest were recorded in 1965, 1977, 1981, 1997, 2002, 2006 and 2010.

In the investigated region there are 18 gauging stations. For project purposes 15 location of gauges have been chosen. The catchment area ranges from 5.80 to $1047.30 \mathrm{~km}^{2}$. The authors are aware that the choice of such a diversified catchments in terms of its size is debatable, but this is the first trial of studies and the results proved that the determined relationships can be useful in estimating the maximum runoff from the Bóbr River basin.

\section{METHODS}

The assessment of the outflow formation during floods occurrence in the investigated area was performed based on the analysis of historical floods waves from multiyear 1970-2004. For this purpose 138 flood waves were chosen from recorded discharge data at 15 gauging stations located on streams and rivers in that region. For the analysis flood waves that fulfilled the following general assumptions were taken:

- discharges of flood waves exceed a threshold value $\mathrm{Q}_{0}$, which designates the beginning and the end of wave hydrograph, called reduced wave hydrograph,

- threshold $\mathrm{Q}_{0}$ has been pre-established as the maximum discharge with a given probability of exceedance $\mathrm{p}=50 \%-\mathrm{Q}_{\max 50 \%}$,

- culmination peak of flood wave is not lower than maximum discharge $\mathrm{Q}_{\max 40 \%}$,

- wave hydrograph is unimodal with one peak.

Applying the above assumption, which was proposed by Gądek [2010, 2014] for floods waves examination in the upper Vistula River, all freshets have been standardized in the same way. Careful selection of real waves in the Bóbr River basin from data set in accordance with general assumptions allowed to eliminate small freshets, with maximum discharges lower than $\mathrm{Q}_{\max 40 \%}$, as waves which do not bring relevant information to a method of maximum outflow assessment from basin. Finally, data set consisted of 106 flood waves.

Each wave hydrograph is characterized by several parameters. For the purpose of the analysis the following parameters were determined:

- $\mathrm{Q}_{\max }$ - maximum discharge of flood waves $\left[\mathrm{m}^{3} \times \mathrm{S}^{-1}\right]$

- $\mathrm{Q}_{\text {red }}$ - value of discharge above threshold, called reduced discharge and equal $\left(\mathrm{Q}_{\max }-\right.$ $\left.\mathrm{Q}_{\max 50 \%}\right)\left[\mathrm{m}^{3} \times \mathrm{s}^{-1}\right]$,

- $t_{k}$ - concentration time of wave at fixed threshold [h],

- $\mathrm{t}_{\mathrm{op}}$ - falling time of wave at fixed threshold [h],

- $t_{t}$ - total time of wave, time of the wave base at fixed threshold determined as $\left(\mathrm{t}_{\mathrm{k}}+\mathrm{t}_{\mathrm{op}}\right)[\mathrm{h}]$,

- $\mathrm{V}_{\mathrm{k}}$ - part of wave volume, determined from the beginning of reduced wave hydrograph to the time when the flood culmination is reached (concentration time) above fixed threshold - volume under a rising limb $\left[\mathrm{mln}^{3}\right]$,

- $\mathrm{V}_{\mathrm{op}}$ - part of wave volume, determined from the time of flood culmination of reduced wave hydrograph to the end of wave above fixed threshold - volume under a falling limb $\left[\mathrm{mln} \mathrm{m}^{3}\right]$,

- $\mathrm{V}_{\mathrm{t}}$ - total volume of wave above fixed threshold, called reduced volume of wave, determined as $\left(\mathrm{V}_{\mathrm{k}}+\mathrm{V}_{\mathrm{op}}\right)\left[\mathrm{mln} \mathrm{m}^{3}\right]$.

Parameters of standardized freshet is shown in the Figure 1. 


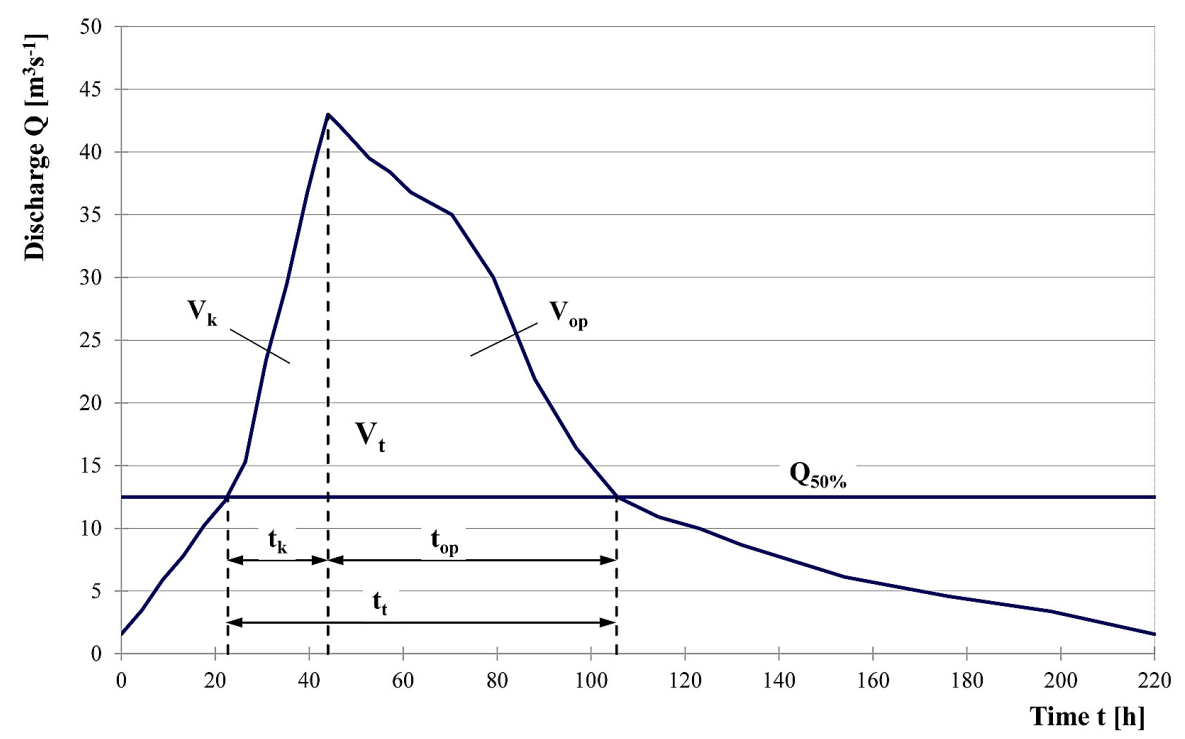

Figure 1. Parameters of standardized freshet

Runoff quantity from a basin is expressed by two kinds of measures: flow and volume. The first measure usually corresponds to mean flow from the basin while the second one results mostly from the flow conversion to volume and represents also a mean value. This is due to that these measures are used predominantly to determine a water balance within a certain period (day, month, year) to describe averaged conditions in a basin. In engineering practice the volume of runoff is estimated quite rarely directly from the wave hydrograph (except the volumes that are necessary for water management in storage reservoirs, but it does not concern the issues discussed in the paper). However, during flood events it is necessary to estimate not only a maximum discharge but also the volume of maximum outflow from basin, that will supply a recipient increasing thereby a flood threat on main river. Therefore, the authors propose to asses a maximum outflow by analysing the volumes of historical flood waves. Such detailed analysis can be useful in the next stage of the project when method of hypothetical flood wave construction will be elaborated.

Investigations were carried out at two levels:

- analysis of wave parameters of all historical waves (106 hydrographs),

- analysis of averaged values of wave parameters determined for each gauging station (15 hydrographs).

Studies on maximum outflow assessment consisted in searching the regional relationships between basic parameters of flood waves recorded in the Bóbr River basin.

\section{RESULTS}

The results presented in the paper refer to the first attempts to estimate the maximum outflow to find out whether it is worth to proceed the proposed way of analysis in the Bóbr River basin. The obtained results have proved to be satisfactory, although the threshold $\mathrm{Q}_{0}$ for freshets standardization, adopted after Gądek [2010, 2014], pre-established as the maximum discharge with a given probability of exceedance $\mathrm{p}=50 \%$, seems to be a bit too high for the Sudeten streams and small rivers. Threshold values $\mathrm{Q}_{\max 50 \%}$ should be verified in the individual river cross-sections in order to check the water level at that flow in relation to the river bank.

It is difficult to show all the obtained regional relationships between basic parameters of standardized flood waves in the paper, therefore, only some of the most interesting are presented. In Figures 2 and 3 two relationships for all standardized flood waves recorded at 15 gauging stations in the Bóbr River basin are shown: total volume $\mathrm{V}_{\mathrm{t}} \mathrm{vs}$ reduced discharge $Q_{\text {red }}$ and value $V_{k} / t_{k}$ vs reduced discharge $Q_{\text {red }}$. Both relationships showed strong correlations which is confirmed by high values of determination coefficients.

Improved regional relationships have proved to be those that were determined by analysing the averaged values of waves parameters, calculated for each gauging station. In Figures 4-6 three relationships are shown: averaged total time $t_{k} v s$ averaged time of concentration $t_{k}$, averaged volume $V_{k}$ vs averaged time of concentration $t_{k}$ and 


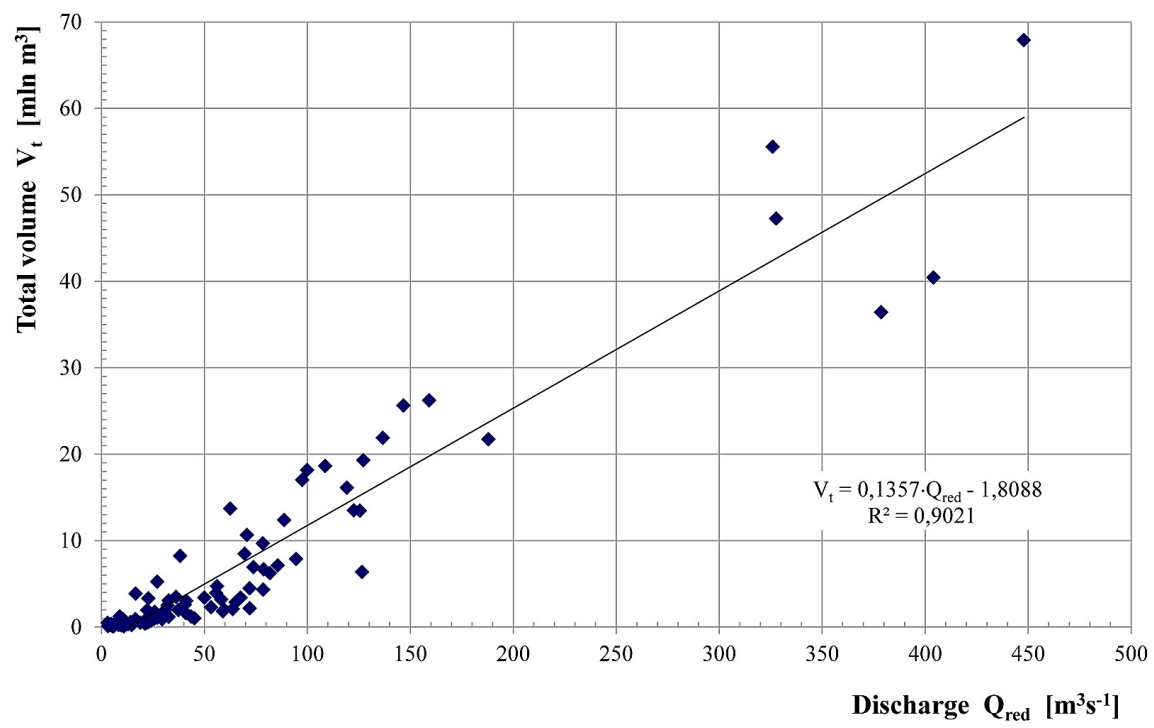

Figure 2. Relationship of total volume $\mathrm{V}_{t}$ of standardized flood waves vs reduced discharge $\mathrm{Q}_{\text {red }}$ for all historical floods recorded in the Bóbr River basin in 1970-2004

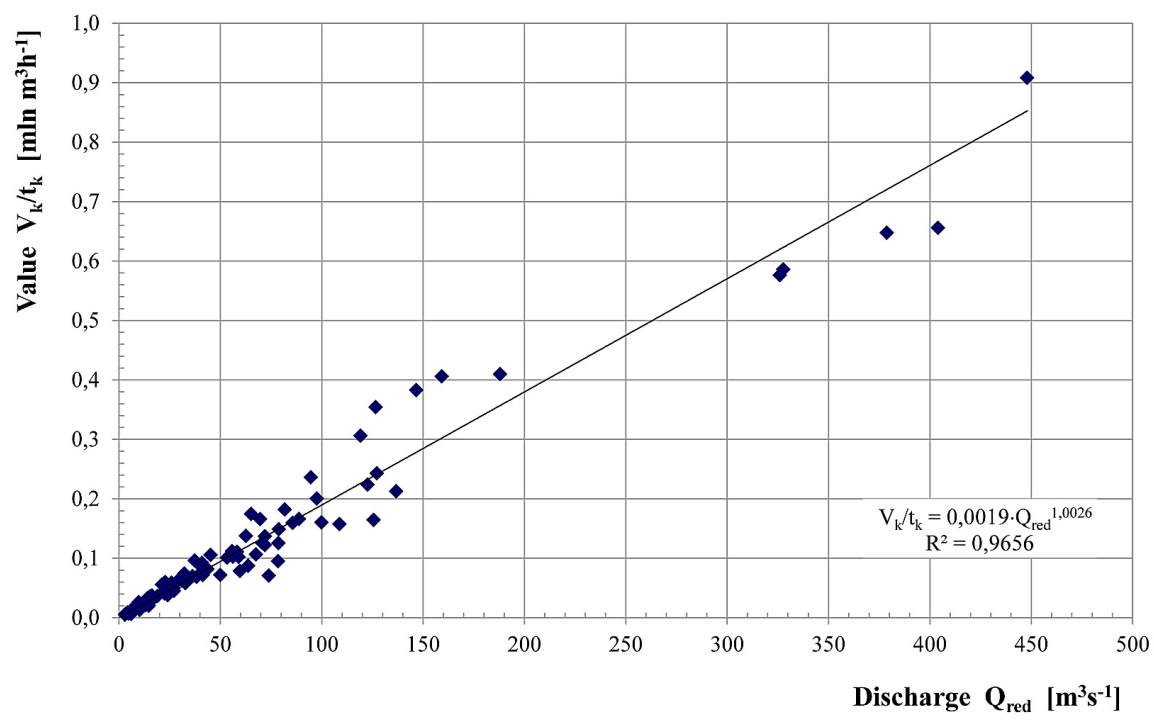

Figure 3. Relationship of total value $\mathrm{V}_{\mathrm{t}} / \mathrm{t}_{\mathrm{k}}$ of standardized flood waves vs reduced discharge $\mathrm{Q}_{\text {red }}$ for all historical floods recorded in the Bóbr River basin in 1970-2004

averaged volume $\mathrm{V}_{\mathrm{t}}$ vs averaged volume $\mathrm{V}_{\mathrm{k}}$. The relationships in figures 4 and 6 showed strong correlations, confirmed by high values of determination coefficients. Relation of averaged volume $\mathrm{V}_{\mathrm{k}}$ vs averaged time of concentration $t_{k}$ presented in figure 5 have weaker correlation but it gives the view on relation of these two parameters during the most important phase of wave formation in the riverbed and valley, i.e. during a rising phase. Three outlier points refer to the following gauging station respectively: above theoretical line Jelenia Góra at the Bóbr River, under theoretical line - Jelenia Góra at the Kamienna River and Cieplice at the Wrzosówka Stream. The authors hope that lowering the threshold will improve this relationship.

In figures 7 and 8 two other interesting regional relationships related to two main parts of wave hydrographs are presented, i.e. rising and falling phases,. The first one gives information on the mutual proportion of the averaged volumes $\mathrm{V}_{\text {op }}$ / $\mathrm{V}_{\mathrm{k}}$ and the averaged durations $\mathrm{t}_{\mathrm{op}} / \mathrm{t}_{\mathrm{k}}$, whereas the second one shows the rate of volume change over time $\mathrm{V}_{\mathrm{k}} / \mathrm{t}_{\mathrm{k}}$ and $\mathrm{V}_{\mathrm{op}} / \mathrm{t}_{\mathrm{op}}$ and their mutual relation in rising and falling phase. Due to rapid growth of water volume in short time in the mountainous streams and rivers the ratio $\mathrm{V}_{\mathrm{k}} / \mathrm{t}_{\mathrm{k}}$ is higher than the ratio $\mathrm{V}_{\mathrm{op}} / \mathrm{t}_{\mathrm{op}}$. 


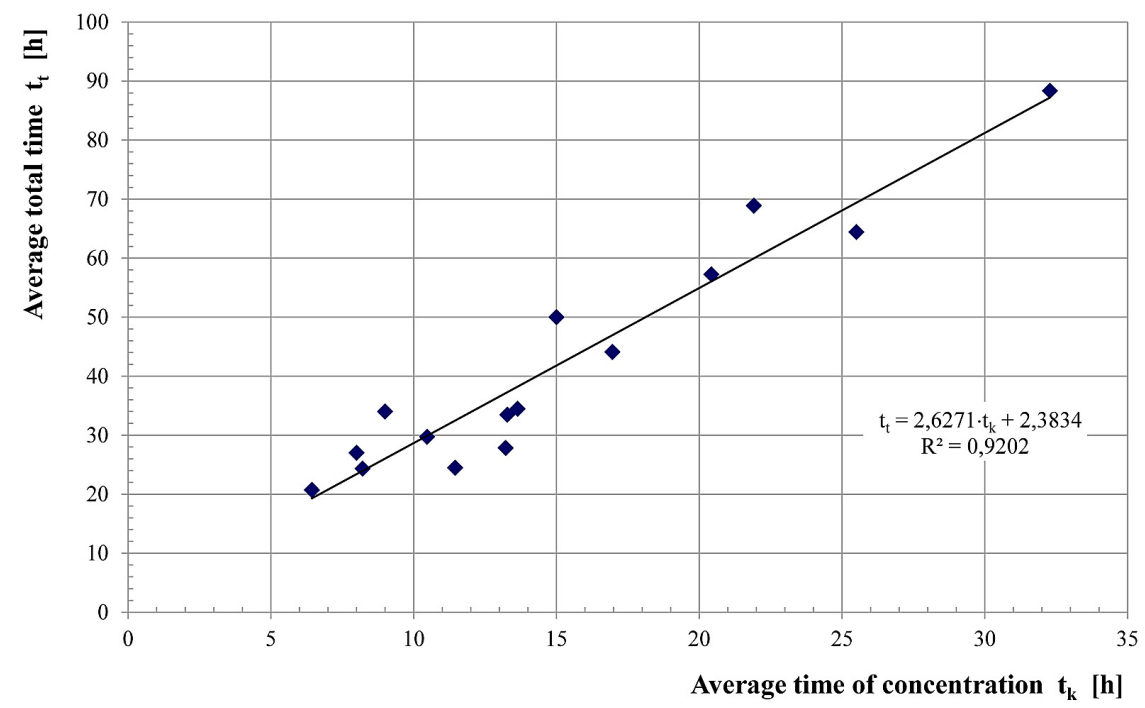

Figure 4. Relationship of averaged total time $t_{t}$ of standardized flood waves vs averaged time of concentration $\mathrm{t}_{\mathrm{k}}$ in the Bóbr River basin in 1970-2004

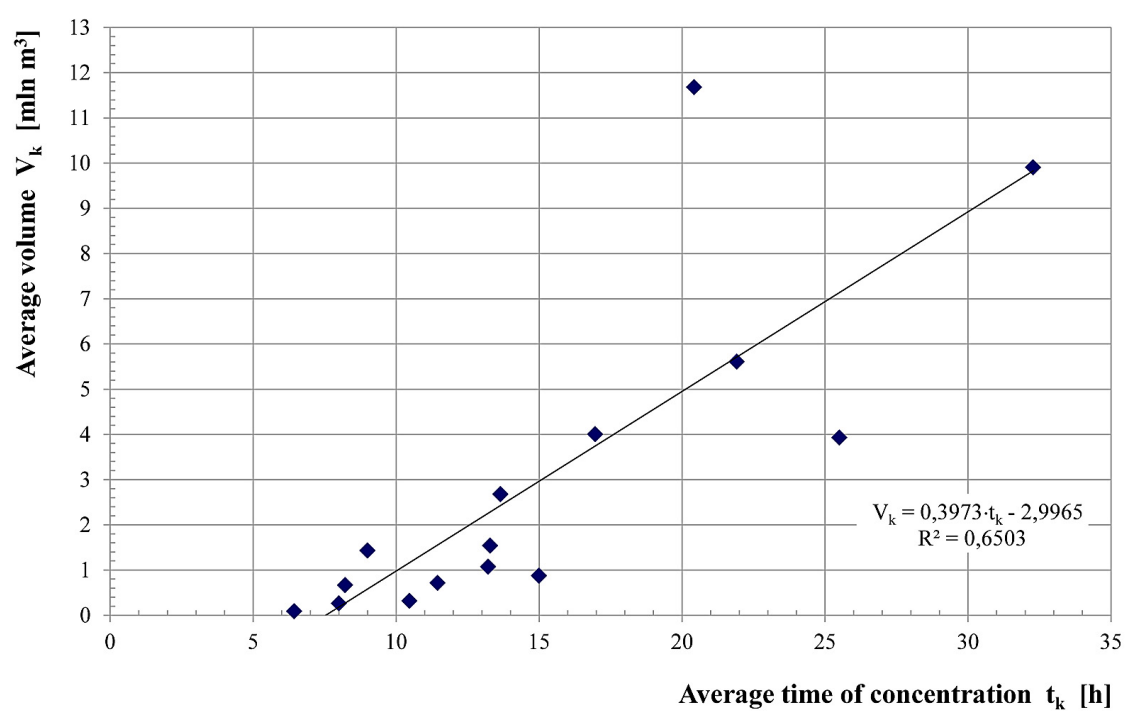

Figure 5. Relationship of averaged volume $\mathrm{V}_{\mathrm{k}}$ of standardized flood waves vs averaged time of concentration $t_{k}$ in the Bóbr River basin in 1970-2004

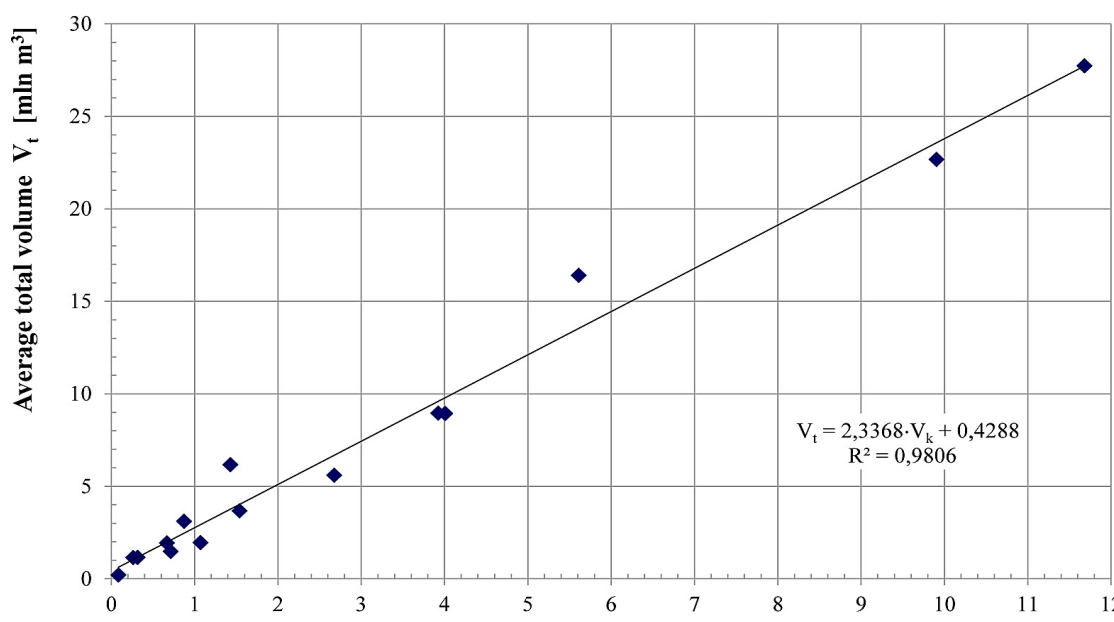

Average volume $V_{k}\left[\mathrm{mln} \mathrm{m}^{3}\right]$

Figure 6. Relationship of averaged volume $\mathrm{V}_{\mathrm{t}}$ vs averaged volume $\mathrm{V}_{\mathrm{k}}$ of standardized flood waves in the Bóbr River basin in 1970-2004 


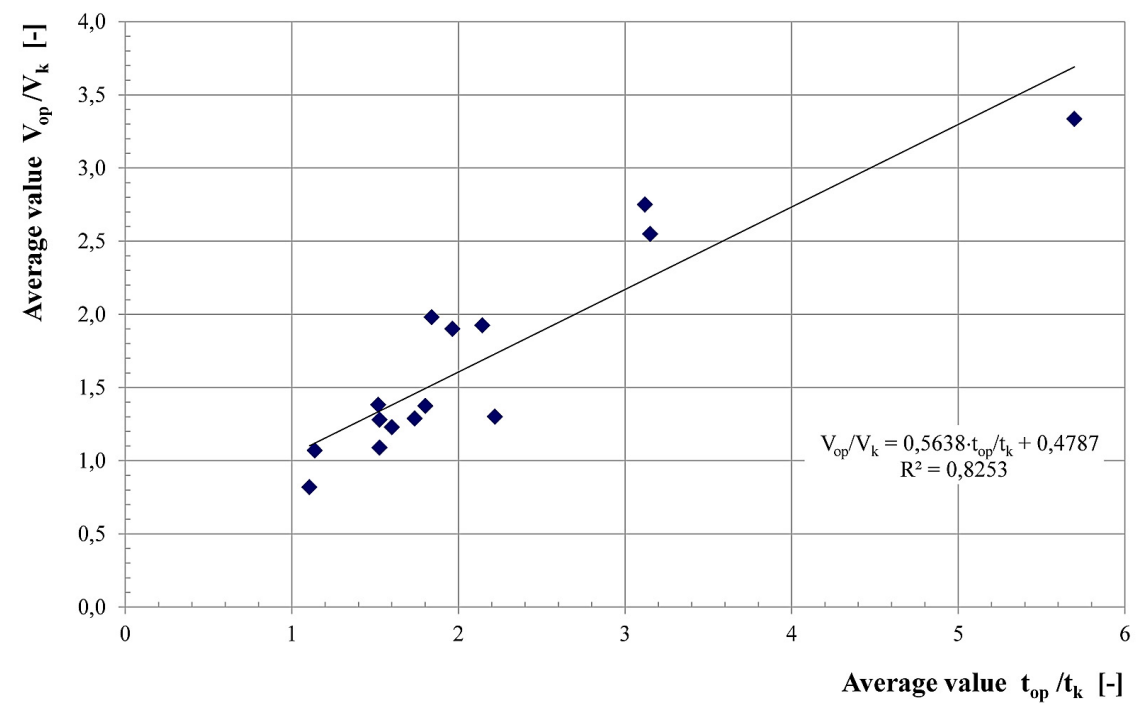

Figure 7. Relationship of averaged value $V_{o p} / V_{k}$ of standardized flood waves vs averaged value $t_{o p} / t_{k}$ in the Bóbr River basin in 1970-2004

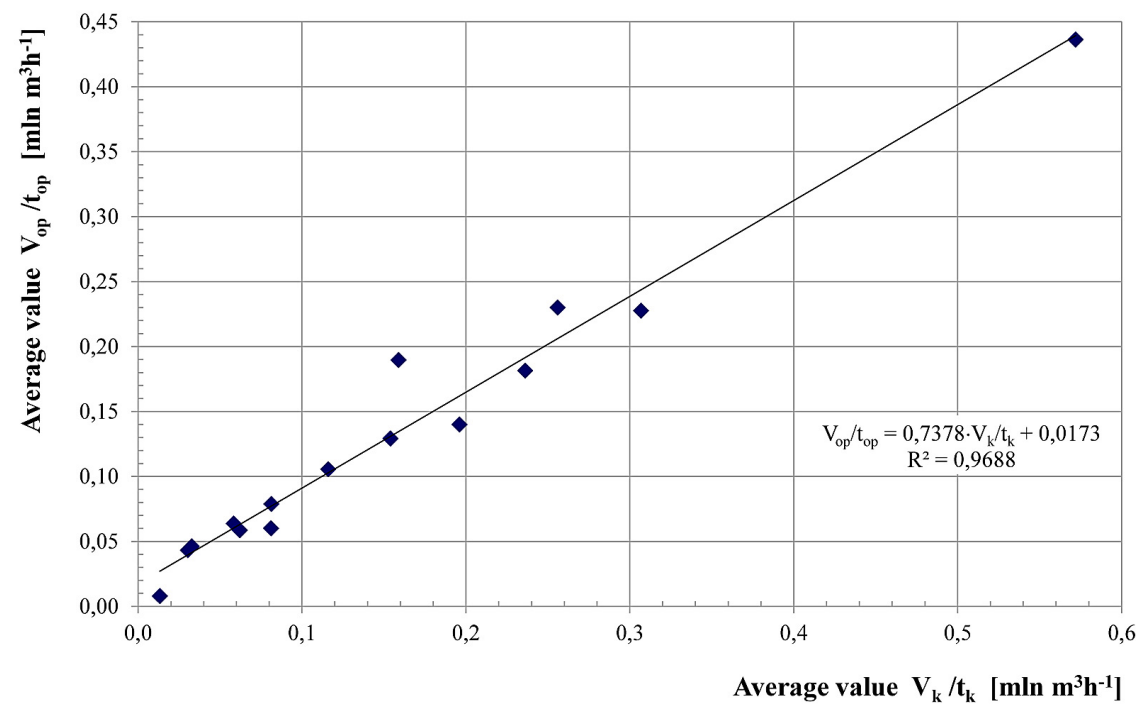

Figure 8. Relationship of averaged value $V_{o p} / t_{\text {op }}$ vs averaged value $V_{k} / t_{k}$ of standardized flood waves in the Bóbr River basin in 1970-2004

\section{CONCLUSIONS}

Regional relationships determined for the Bóbr River basin are satisfactory. Most of them showed strong correlations, confirmed by high values of determination coefficients. The obtained relations between waves parameters give a view on the course of flood events and the maximum outflow formation in the basin. They can be helpful in estimating the volume, duration and maximum discharge during rising and falling phase of wave but also for the total wave. They can also be useful in assessing the share of the outflow from the Bóbr River in the outflow of the Odra River, in esti- mating a wave formation in riverbed and valley and then their draining, in determining the rate of filling by water volume and emptying riverbed and valley. Recapitulating, regional relationships can be useful in flood protection issues.

A proper recognition of interrelationships between waves parameters will be helpful in developing the method of hypothetical flood wave construction for streams and rivers in the Sudety Mountain which is to be performed in the next stage of the project.

Standardization of historical freshets has helped their analysing by eliminating individual interpretation of the input data. Compari- 
son of preliminary relationships (not discussed in the paper) elaborated for freshets with wave parameters determined on different levels of $\mathrm{Q}_{0}$ with those which were determined for standardized waves, indicates that the latter are much better and more preferred .

The analysis suggests that threshold $\mathrm{Q}_{0}$ for freshets standardization, pre-established as the maximum discharge $\mathrm{Q}_{\max 50 \%}$ should be verified in the individual river cross-sections in order to check the water level at that flow, in relation to the river bank. The authors expect that such a verification will improve the relationships. In further analysis of maximum outflow formation in the Bóbr River basin the catchments parameters that have a significant impact on runoff will be included and perhaps new interesting relationships could be determined. There is also a need to extend the multiyear for another 10 year, i.e. until 2014.

\section{REFERENCES}

1. Dubicki A., Kosierb R., Działa I., Wilk-Stawarz B., Głowicki B., Chudzik B., Bogucki J., Bogusz A., Tokarczyk T. 2013. Uwarunkowania hydrologiczno-meteorologiczne i hydrotechniczne Odrzańskiej Drogi Wodnej. [In:] Odrzańska Droga Wodna. Dolnośląskie Wydawn. Edukacyjne, Wrocław, 45-71.

2. Gądek W. 2010. Fale hipotetyczne o zadanym prawdopodobieństwie przepływu w kulminacji. [In:] Hydrologia w inżynierii i gospodarce wodnej. T. 1. Monografia Nr 68. Komitet Inżynierii Środowiska PAN, Warszawa, 177-186.

3. Gądek W. 2014. Fale hipotetyczne dla zlewni niekontrolowanej. [In:] Hydrologia w inżynierii i gospodarce wodnej, t. 1, z. XX, Monografie Komitetu Gospodarki Wodnej PAN, Warszawa, 139-149.

4. Olearczyk D. 2001. Regionalne zależności przepływów maksymalnych w dorzeczu górnej i środkowej Odry. Inżynieria Środowiska XII. Zesz. Nauk. AR Wrocław, No. 413, 159-186. 